\title{
Molecular detection of $E$.coli virulence genes causing broiler cellulitis at Ismailia Governorate
}

Enany M. E.; Moursi M. K.* and Rana, M. A. El-Fattah ${ }^{* *}$

Bacteriology, Immunology and Mycology Department, Faculty of Veterinary Medicine, Suez Canal University. "Reference Laboratory for Veterinary Quality Control on Poultry Productlion, Animal Health Research Institute, Egypt.

\begin{abstract}
This study was conducted to investigate the existence of virulence genes among Escherichia coli strains isolated from cellulitis lesions in broiler chickens. Total of (103) defeathered broiler carcasses were collected from different slaughter houses during carcasses inspection at Ismailia province. Samples were collected from moist lesion in subcutaneous tissue and fibrinopurulent material for bacteriological examination. Biochemical and serological identification of E.coli isolates were carried out as well as detection of virulence genes (iss, iutA, tsh, kpsMTII, papC, stxl, traT and cvaC) by PCR protocol. The result showed that E.coli was isolated from 51 out of 103 examined carcasses $(49.51 \%)$. The isolated E.coli serologically belonged to O125, O158, O169 and untyped ones. Virulence genes were detected among selected E.coli strains derived from cellulitis lesions with variable percentage. All examined isolates were positive for presence of traT and papC genes, $80 \%$ of isolates were positive for iss, iutA and $\mathrm{kpsMTII}$ genes, $60 \%$ of isolates were positive for $\mathrm{cvaC}$ gene and $20 \%$ of isolates were positive for tsh gene. None of the isolates harbored the stxl gene.
\end{abstract}

Key words: Virulence Genes - Escherichia coli - Cellulitis - Broiler Chickens - PCR.

\section{Introduction}

Escherichia coli causes a variety of diseases in poultry, including respiratory tract infection, omphalitis, swollen-head syndrome, enteritis, septicemia and cellulitis and these diseases are responsible for major economic losses in the chicken industry (Gross, 1994 and Norton, 1997). Avian cellulitis is an economically important disease of broiler chickens was first reported in 1984 in Great Britain (Randall et al, 1984). It is an infection of the subcutaneous tissues of the skin, which leads to the production of fibrinous plaques (Gross, 1994). It has also been called infectious process, inflammatory process, or necrotic dermatitis (Barnes and Gross, 1997; Norton, 1997; DhoMoulin and Fairbrother, 1999). Generally, it is associated with a scratch or skin break on the thighs 
or lower abdomen of broiler chickens (Norton, 1997). Cellulitis is not associated with clinical illness and does not seem to affect the growth of the bird (Elfadil et al, 1996). The infection is generally detected at the time of slaughter (Gross, 1994).

Escherichia coli were the predominant bacteria isolated from cellulitis lesions. It appears that the E.coli is capable of causing cellulitis must have some special characteristics such as virulence factors. The virulence factors include aerobactin, colicin and cytotoxin are required for the E.coli strain to be causative (Peighambari et al, 1995 and Norton et al, 2000). The virulence genes that permit certain intestinal commensal E.coli to become avian pathogenic E.coli (APEC) and infect extraintestinal sites include those encoding for the adhesins type 1fimbriae and temperature-sensitive

hemagglutinin $(t s h), \quad$ ironscavenging systems and the protectin (iss) (Dziva and Stevens, 2008).

Most of these genes are often carried on Colicin V ( ColV) or other large plasmids and are thought to enable APEC strains to adhere to host tissues survive within host fluids and resist host immune defenses. Different APEC strains may have unique combinations of different virulence factors that have similar functions with regards to disease establishment (Johnson et al, 2006 and Mellata et al, 2010).
The objective of this study was molecular detection of E.coli virulence genes causing broiler cellulitis in Ismailia Governorate using polymerase chain reaction (PCR) as a rapid diagnosis for genotypic characterization.

\section{Material and Methods}

\section{1- Collection of samples}

A total of 103 defeathered broiler carcasses with gross skin lesions (abnormal area characterized by brown discoloration, thickened and scabby) were collected from different flocks in slaughter houses at Ismailia province. The samples were transported in ice to the laboratory, immediately examined and subjected to isolation and identification of Escherichia coli.

2-Isolation and identification of Escherichia coli

A sterile swab was used to collect fibrinopurulent material for bacteriological examinations. All swabs were inoculated in buffer peptone water and incubated at $37^{\circ} \mathrm{C}$ for $18 \pm 2$ hrs under aerobic condition. A loopful from each sample was separately streaked onto MacConkey's agar and Eosin Methylene Blue agar (EMB) and incubated at $37^{\circ} \mathrm{C}$ for $24 \mathrm{hr}$. Suspected colonies were picked up, subjected to morphological and Gram staining reaction then streaked on nutrient agar slope for further identification and also in semi-solid agar for detection of motility and finally for preservation. Suspected isolates were confirmed 
by a series of biochemical identification according to (Murray et $\boldsymbol{a l}, 2003$ ) as well as serotyping by slide agglutination test according to (Lee et al, 2009) using standard polyvalent and monovalent E.coli antisera.

2-Molecular characterization of E.coli isolates using conventional PCR (cPCR):

Five E.coli isolates were subjected to cPCR for detection of these virulence genes (iss, iutA, tsh, kpsMTII, papC, stxl, traT and cvaC).

3.1. Extraction of E.coli DNA: using ABIOpure Genomic DNA extraction kit instructions (Cat. No. M501DP100).
3.2. Preparation of PCR Master Mix According to Emerald Amp GT PCR master mix (Takara) Code No. RR310A kit as shown in Table (2).

3.3. Cycling conditions of the primers during cPCR: Temperature and time conditions of the primers during PCR are shown in Table (3) according to specific authors and Emerald Amp GT PCR master mix (Takara) kit.

3.4. Agarose gel electrophoreses (Sambrook et al., 1989).

DNA Molecular weight marker: using Gene ruler 100 bp plus DNA ladder (cat. no. SM0323) supplied from Fermentas with size range: 100-3000 bp.

Table (1): Oligonucleotide primers sequences source: Midland Certified Reagent Company_oilgos (USA).

\begin{tabular}{|c|c|c|c|}
\hline Gene & $\begin{array}{c}\text { Primer Sequence } \\
5^{\prime}-3^{\prime} \\
\end{array}$ & $\begin{array}{c}\text { Amplified } \\
\text { product }\end{array}$ & Reference \\
\hline \multirow{2}{*}{$t s h$} & GGTGGTGCA CTG GAG TGG & \multirow{2}{*}{$620 \mathrm{bp}$} & \multirow{2}{*}{$\begin{array}{l}\text { Delicato et al. } \\
\quad(2003)\end{array}$} \\
\hline & AGT CCA GCG TGA TAG TGG & & \\
\hline \multirow{2}{*}{ papC } & TGATATCACGCAGTCAGTAGC & \multirow{2}{*}{$501 \mathrm{bp}$} & \multirow{2}{*}{$\begin{array}{c}\text { Wen-jie et al. } \\
\quad(2008)\end{array}$} \\
\hline & CCGGCCATATTCACATAA & & \\
\hline \multirow{2}{*}{ iss } & ATGTTATTTTCTGCCGCTCTG & \multirow{2}{*}{$266 \mathrm{bp}$} & \multirow{6}{*}{$\begin{array}{l}\text { Yaguchi et al. } \\
\quad(2007)\end{array}$} \\
\hline & CTATTGTGAGCAATATACCC & & \\
\hline \multirow{2}{*}{ iutA } & GGCTGGACATGGGAACTGG & \multirow{2}{*}{$300 \mathrm{bp}$} & \\
\hline & CGTCGGGAACGGGTAGAATCG & & \\
\hline \multirow{2}{*}{$c v a C$} & CACACACAAACGGGAGCTGTT & \multirow{2}{*}{$760 \mathrm{bp}$} & \\
\hline & CTTCCCGCAGCATAGTTCCAT & & \\
\hline \multirow{2}{*}{ kpsMTII } & CAGGTAGCGTCGAACTGTA & \multirow{2}{*}{$280 \mathrm{bp}$} & \multirow{2}{*}{$\begin{array}{c}\text { Ewers et al. } \\
\text { (2007) }\end{array}$} \\
\hline & CATCCAGACGATAAGCATGAGCA & & \\
\hline \multirow{2}{*}{ stxl } & ACACTGGATGATCTCAGTGG & \multirow{2}{*}{$614 \mathrm{bp}$} & \multirow{2}{*}{$\begin{array}{c}\text { Dipineto et al. } \\
(2006)\end{array}$} \\
\hline & CTGAATCCCCCTCCATTATG & & \\
\hline \multirow{2}{*}{$\operatorname{traT}$} & GATGGCTGAACCGTGGTTATG & \multirow{2}{*}{$307 \mathrm{bp}$} & \multirow{2}{*}{$\begin{array}{l}\text { Kaipainen et al. } \\
\quad(2002)\end{array}$} \\
\hline & CACACGGGTCTGGTATTTATGC & & \\
\hline
\end{tabular}

Table (2): Preparation of PCR master mix 


\begin{tabular}{|c|c|}
\hline Component & Volume/reaction \\
\hline Emerald Amp GT PCR master mix (2x premix) & $12.5 \mu l$ \\
\hline PCR grade water & $4.5 \mu l$ \\
\hline Forward primer (20 pmol) & $1 \mu l$ \\
\hline Reverse primer (20 pmol) & $1 \mu l$ \\
\hline Template DNA & $6 \mu l$ \\
\hline Total & $25 \mu l$ \\
\hline
\end{tabular}

Table (3): Cycling conditions of the different primers during $C P C R$

\begin{tabular}{|c|c|c|c|c|c|c|c|}
\hline Gene & $\begin{array}{c}\text { Primary } \\
\text { denaturation }\end{array}$ & $\begin{array}{c}\text { Secondary } \\
\text { denaturation }\end{array}$ & Annealing & Extension & $\begin{array}{l}\text { No.of } \\
\text { cycles }\end{array}$ & $\begin{array}{c}\begin{array}{c}\text { Final } \\
\text { extension }\end{array} \\
\end{array}$ & Reference \\
\hline phoA & $\begin{array}{c}94^{\circ} \mathrm{C} \\
10 \mathrm{~min} .\end{array}$ & $\begin{array}{c}94^{\circ} \mathrm{C} \\
45 \mathrm{sec}\end{array}$ & $\begin{array}{c}58^{\circ} \mathrm{C} \\
40 \mathrm{sec} .\end{array}$ & $\begin{array}{c}72^{\circ} \mathrm{C} \\
45 \mathrm{sec} .\end{array}$ & 35 & $\begin{array}{c}72^{\circ} \mathrm{C} \\
10 \mathrm{~min} .\end{array}$ & $\begin{array}{c}\text { Hu et al } \\
\text { (2011) }\end{array}$ \\
\hline$t s h$ & $\begin{array}{l}94^{\circ} \mathrm{C} \\
5 \mathrm{~min} .\end{array}$ & $\begin{array}{c}94^{\circ} \mathrm{C} \\
45 \mathrm{sec} .\end{array}$ & $\begin{array}{c}54^{\circ} \mathrm{C} \\
45 \mathrm{sec} .\end{array}$ & $\begin{array}{c}72^{\circ} \mathrm{C} \\
45 \mathrm{sec} .\end{array}$ & 35 & $\begin{array}{c}72^{\circ} \mathrm{C} \\
10 \mathrm{~min} .\end{array}$ & $\begin{array}{c}\text { Delicato } \\
\text { et al } \\
(2003) \\
\end{array}$ \\
\hline papC & $\begin{array}{l}94^{\circ} \mathrm{C} \\
5 \mathrm{~min} .\end{array}$ & $\begin{array}{c}94^{\circ} \mathrm{C} \\
45 \mathrm{sec} .\end{array}$ & $\begin{array}{c}59^{\circ} \mathrm{C} \\
45 \mathrm{sec} .\end{array}$ & $\begin{array}{c}72^{\circ} \mathrm{C} \\
45 \mathrm{sec} .\end{array}$ & 35 & $\begin{array}{c}72^{\circ} \mathrm{C} \\
10 \mathrm{~min} .\end{array}$ & $\begin{array}{c}\text { Wen-jie } \\
\text { et al } \\
(\mathbf{2 0 0 8})\end{array}$ \\
\hline iss & $\begin{array}{l}94^{\circ} \mathrm{C} \\
5 \mathrm{~min} .\end{array}$ & $\begin{array}{c}94^{\circ} \mathrm{C} \\
30 \mathrm{sec} .\end{array}$ & $\begin{array}{c}54^{\circ} \mathrm{C} \\
30 \mathrm{sec} .\end{array}$ & $\begin{array}{c}72^{\circ} \mathrm{C} \\
30 \mathrm{sec} .\end{array}$ & 35 & $\begin{array}{l}72^{\circ} \mathrm{C} \\
7 \mathrm{~min} .\end{array}$ & \multirow{3}{*}{$\begin{array}{c}\text { Yaguchi } \\
\text { et al } \\
(2007)\end{array}$} \\
\hline iutA & $\begin{array}{c}94^{\circ} \mathrm{C} \\
5 \mathrm{~min} .\end{array}$ & $\begin{array}{c}94^{\circ} \mathrm{C} \\
30 \mathrm{sec} .\end{array}$ & $\begin{array}{c}63^{\circ} \mathrm{C} \\
30 \mathrm{sec} .\end{array}$ & $\begin{array}{c}72^{\circ} \mathrm{C} \\
30 \mathrm{sec} .\end{array}$ & 35 & $\begin{array}{l}72^{\circ} \mathrm{C} \\
7 \mathrm{~min} .\end{array}$ & \\
\hline$c v a C$ & $\begin{array}{c}94^{\circ} \mathrm{C} \\
10 \mathrm{~min} .\end{array}$ & $\begin{array}{l}94^{\circ} \mathrm{C} \\
1 \mathrm{~min} .\end{array}$ & $\begin{array}{l}63^{\circ} \mathrm{C} \\
1 \mathrm{~min} .\end{array}$ & $\begin{array}{l}72^{\circ} \mathrm{C} \\
1 \mathrm{~min} .\end{array}$ & 35 & $\begin{array}{c}72^{\circ} \mathrm{C} \\
10 \mathrm{~min} .\end{array}$ & \\
\hline kpsMTII & $\begin{array}{l}94^{\circ} \mathrm{C} \\
5 \mathrm{~min} .\end{array}$ & $\begin{array}{c}94^{\circ} \mathrm{C} \\
30 \mathrm{sec} .\end{array}$ & $\begin{array}{c}54^{\circ} \mathrm{C} \\
30 \mathrm{sec} .\end{array}$ & $\begin{array}{c}72^{\circ} \mathrm{C} \\
30 \mathrm{sec} .\end{array}$ & 35 & $\begin{array}{l}72^{\circ} \mathrm{C} \\
7 \mathrm{~min} .\end{array}$ & $\begin{array}{c}\text { Ewers } e t \\
\text { al. (2007) }\end{array}$ \\
\hline stx 1 & $\begin{array}{c}94^{\circ} \mathrm{C} \\
10 \mathrm{~min} .\end{array}$ & $\begin{array}{l}94^{\circ} \mathrm{C} \\
1 \mathrm{~min} .\end{array}$ & $\begin{array}{c}58^{\circ} \mathrm{C} \\
1 \mathrm{~min} .\end{array}$ & $\begin{array}{l}72^{\circ} \mathrm{C} \\
1 \mathrm{~min} .\end{array}$ & 35 & $\begin{array}{c}72^{\circ} \mathrm{C} \\
10 \mathrm{~min} .\end{array}$ & $\begin{array}{c}\text { Dipineto } \\
\text { et al } \\
(\mathbf{2 0 0 6})\end{array}$ \\
\hline $\operatorname{traT}$ & $\begin{array}{l}95^{\circ} \mathrm{C} \\
5 \mathrm{~min} .\end{array}$ & $\begin{array}{l}94^{\circ} \mathrm{C} \\
1 \mathrm{~min} .\end{array}$ & $\begin{array}{l}55^{\circ} \mathrm{C} \\
1 \mathrm{~min} .\end{array}$ & $\begin{array}{l}72^{\circ} \mathrm{C} \\
1 \mathrm{~min} .\end{array}$ & 35 & $\begin{array}{l}72^{\circ} \mathrm{C} \\
7 \mathrm{~min} .\end{array}$ & $\begin{array}{c}\text { Kaipainen } \\
\text { et al } \\
(\mathbf{2 0 0 2})\end{array}$ \\
\hline
\end{tabular}

\section{Results}

\section{1- Carcasses inspection:}

In all 103 examined cases, the cellulitis lesion was located between the thigh and the ventral midline or in the region of the back and the thighs with yellowish brown discolorations of broiler chicken skin. In some samples, both sides were involved. The lesions varied from small localized lesions $(<1$ $\mathrm{cm})$ to very extensive ones $(>10$ $\mathrm{cm})$. The presence of a loosely attached yellow fibrinous plaque 
in the subcutaneous tissue was a common feature of most lesions, Ulcerative lesion of cellulitis with underlying pus formation located at thigh as shown in photo (1). Other showed thickened and brown discolouration skin in photo (2).

2- Bacteriological examination:

The results of bacteriological examination were presented in Table (4).

3- Serotyping:

The E.coli isolates taken from cellulitis lesions were distributed

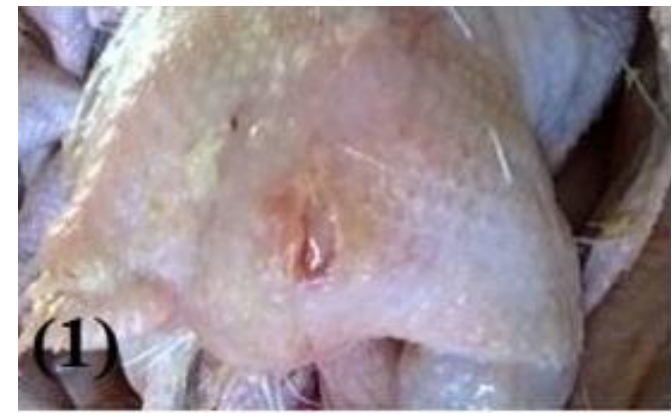

among 3 different $\mathrm{O}$ serotype groups (O125, O158 and O169) besides untypable ones.

4- Molecular characterization of E.coli isolates using conventional PCR (cPCR):

Photo (3), (4), (5), (6), (7) and Table (5) showed the amplification and the detection of 8 virulence genes (iss, iutA, tsh, kpsMTII, papC, stxl, traT and $(v a C)$ in the five E.coli isolates.

Table (4): Prevalence of E.coli isolated from cellulitis lesions from broiler chickens

\begin{tabular}{|c|c|c|c|}
\hline \multirow{2}{*}{ Type of samples } & \multirow{2}{*}{$\begin{array}{c}\text { Total number of the } \\
\text { collected samples }\end{array}$} & \multicolumn{2}{|c|}{$\begin{array}{c}\text { Positive } \text { E.coli } \\
\text { isolates }\end{array}$} \\
\cline { 3 - 4 } & 43 & No. & $\%$ \\
\hline Thigh & 60 & 20 & 39.2 \\
\hline Breast & $\mathbf{1 0 3}$ & 31 & 60.8 \\
\hline Total S.C samples & \multicolumn{51}{|c|}{} \\
\hline
\end{tabular}




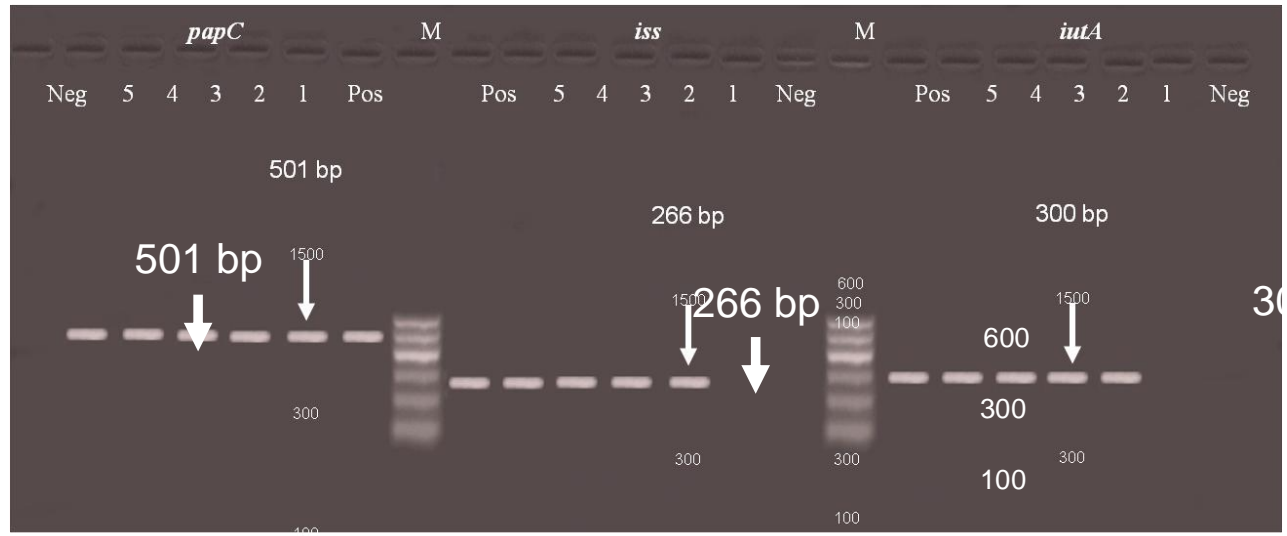

Photo (3): Agarose gel electrophoresis of amplified papC (501 bp), iss (266 $\mathrm{bp}$ ) and iutA gene PCR product (300 bp).

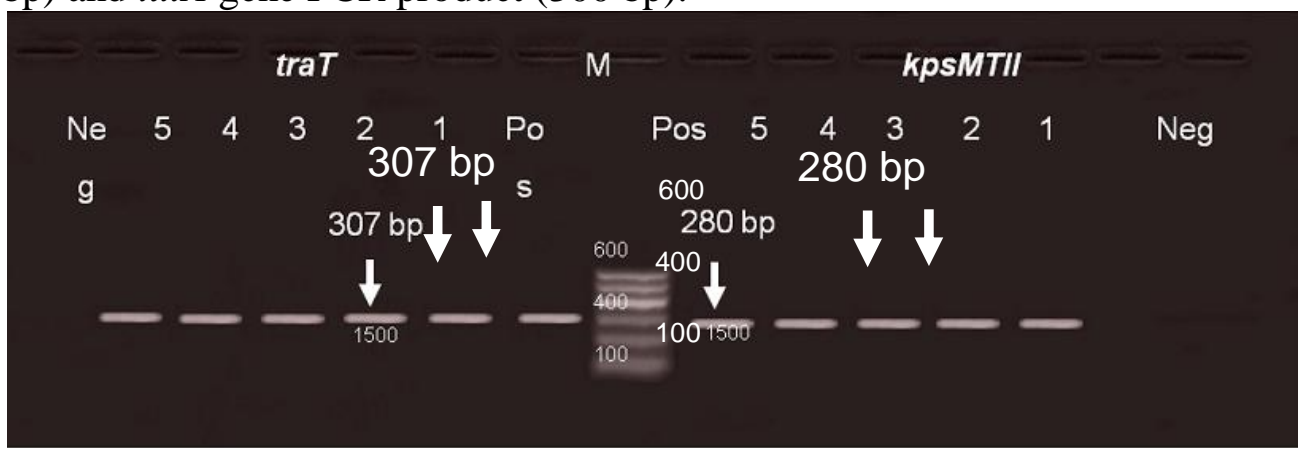

Photo (4): Agarose gel electrophoresis of amplified traT (307 bp) and kpsMTII gene PCR product (280 bp).

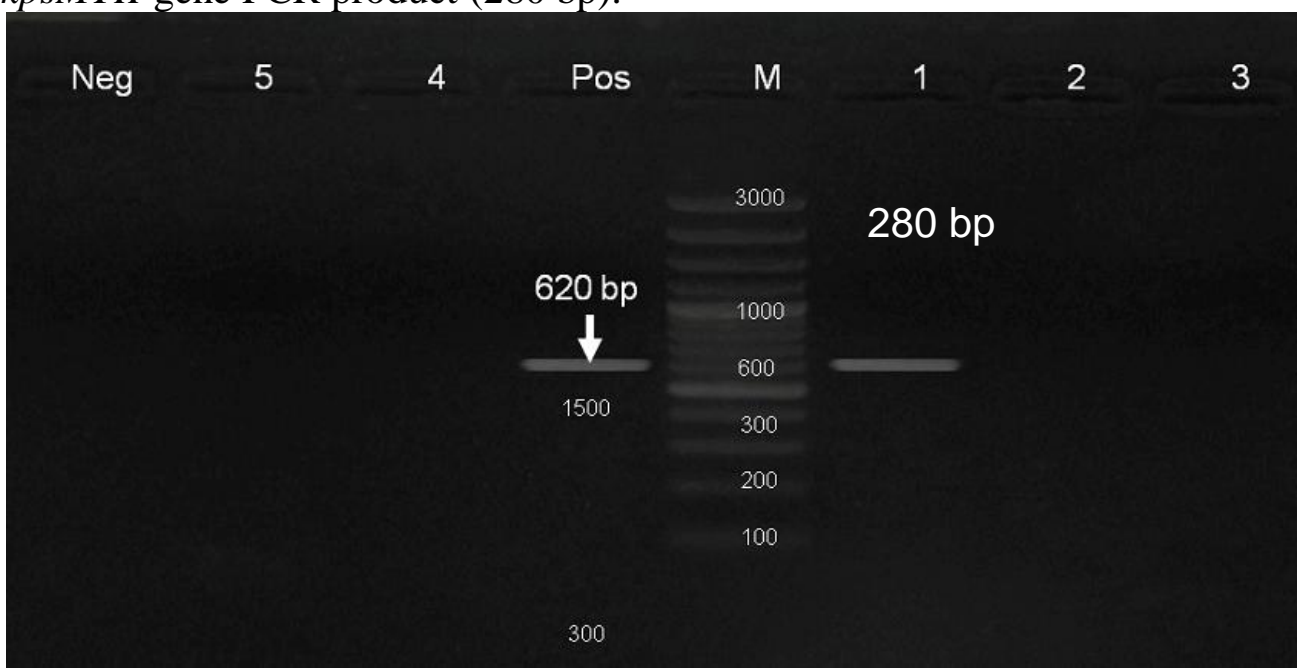

Photo (5): Agarose gel electrophoresis of amplified $t s h$ PCR product (620 bp). 


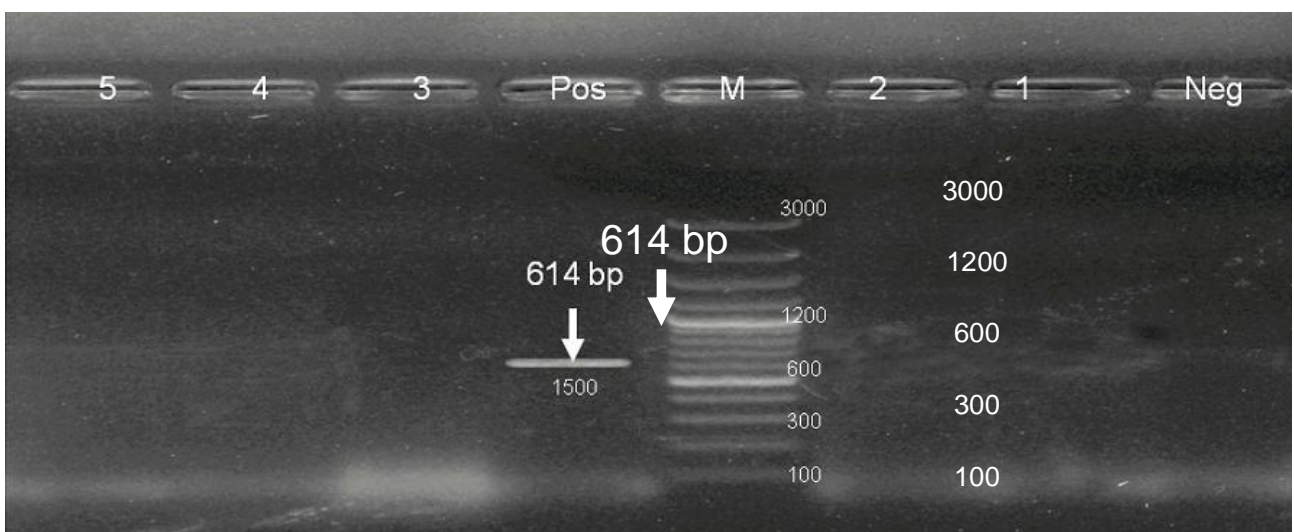

Photo (6): Agarose gel electrophoresis of amplified stxl PCR product (614 bp).

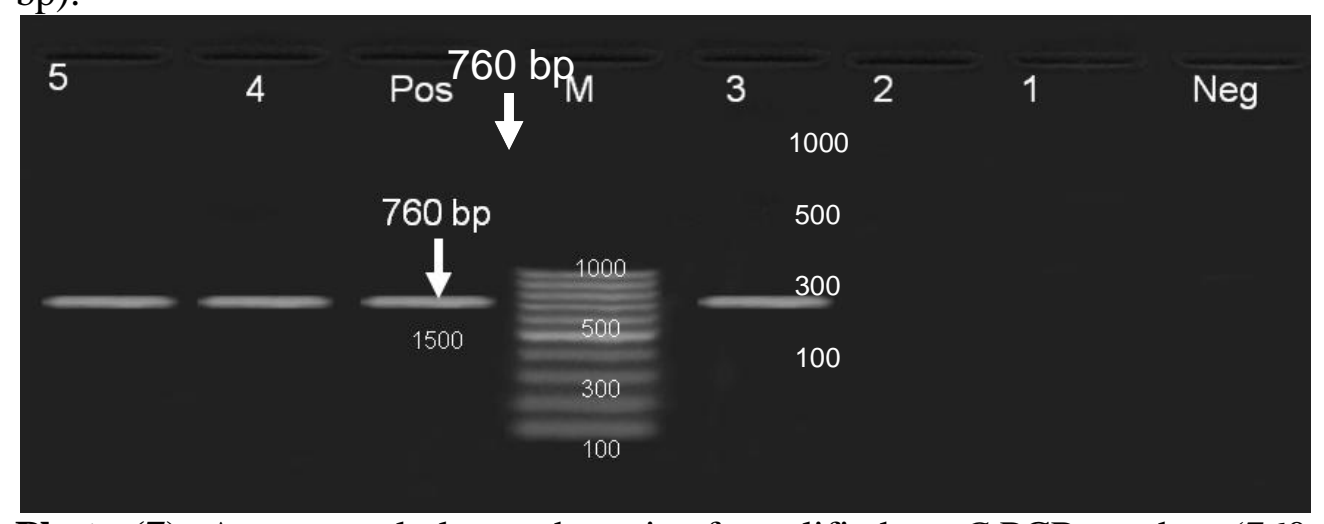

Photo (7): Agarose gel electrophoresis of amplified $c v a C$ PCR product (760 bp).

L1: E.coli O169.

L2: Untypable E.coli (No. 1).

L3: E.coli $\mathrm{O} 158$.

L4: E.coli $\mathrm{O} 125$.

L5: Untypable E.coli (No. 2).

Table (5): Prevalence of virulence genes (iss, iutA, tsh, kpsMTII, papC, stxl, traT and cvaC) detected by $c P C R$ among examined E.coli strains.

\begin{tabular}{|c|c|c|}
\hline Virulence genes & E.coli isolates & \% \\
\hline iss & $4 / 5$ & 80 \\
iutA & $4 / 5$ & 80 \\
tsh & $1 / 5$ & 20 \\
kpsMTII & $4 / 5$ & 80 \\
papC & $5 / 5$ & 100 \\
stxl & $0 / 5$ & 0 \\
traT & $5 / 5$ & 100 \\
cvaC & $3 / 5$ & 60 \\
\hline
\end{tabular}




\section{Discussion:}

Coliform cellulitis has emerged as a significant disease since its description in 1984 (Randall et al, 1984) because of increased condemnations, downgrading at processing, and higher labor costs to process affected flocks (Lisa et al, 2013).

Cellulitis is one of the most prevalent extraintestinal infections caused by avian pathogenic E.coli (APEC) in broiler chickens and is characterized by the presence of subcutaneous fibrinonecrotic plaques and inflammation of the overlying chicken skin, resulting in rejection of part or all of the carcasses at processing (De Brito et al, 2003).

The results of carcass inspection and gross lesions revealed that, in 103 examined cases, the cellulitis lesions was located between the thigh and the ventral midline or in the region of the back and the thighs with yellowish brown discolorations of the skin of broiler chicken. In some cases, both sides were involved. The lesions varied from small localized lesions $(<1 \mathrm{~cm})$ to very extensive ones $(>10 \mathrm{~cm})$. The presence of a loosely attached yellow fibrinous plaque in the subcutaneous tissue was a common feature of most lesions . Muscles under the fibrinous plaques usually showed streaky hemorrhages or focal hyperemia, and fluid was present at the site of lesions or ulcerative lesion with underlying pus formation located at thigh in some cases. Other showed thickened and brown discoloration skin. Similar gross lesions were recorded during carcass inspection with cellulitis by (Derakhshanfar and Ghanbarpour, 2002 and Lisa et al, 2013).

Escherichia coli isolation incidence was $49.51 \%$ from broilers with cellulitis lesions which was lower than that reported by many authors; Gomis et al (1997) isolated E.coli in pure culture from cellulitis lesion by (97.5\%). Onderka et al (1997) isolated E.coli from cellulitis lesion by ( $83 \%)$. Also Derakhshanfar and Ghanbarpour (2002) isolated E.coli by $(91.8 \%)$ from cellulitis lesions of examined broiler's carcasses. While, recently Barros et al (2013) isolated E.coli from cellulitis lesion by $(82.5 \%)$.

Concerning, serotyping results revealed that E.coli isolates were distributed among 3 different $\mathrm{O}$ serotype groups (O125, O158 and O169) besides untypable ones. The obtained results agreed to some extent with $\mathrm{O}$ serotype groups reported by other researchers as Gomis et al (1997 \& 2001) who isolated E.coli (O125) and (O158) from cellulitis lesions. While Allan (2012) isolated E.coli (O158) from birds suffered from cellulitis. Also Mohamed et al (1997) isolated E.coli $\mathrm{O} 125$ from chickens with facial cellulitis.

However, genotyping characterization has shown that the prevalence of pathogenic E.coli in a broiler house was independent of 
the prevalence of other E.coli in the environment. DNA fingerprinting identified the presence of endemic populations of specific cellulitisassociated E.coli existing in the broiler house environment. These organisms persist for at least 6 months, irrespective of partial or complete cleaning and disinfection and cause coliform cellulitis in successive flocks (Lisa et al, 2013). Although many techniques can be used to identify virulence factors, the PCR still a powerful technique for detection of pathogens because of its rapidity, specificity and sensitivity. It is an effective procedure for generating large quantities of a specific DNA sequence in vitro (Holland et al, 2000).

The E.coli isolates were subjected for the detection of the virulence genes (papC, iss, iutA, tsh, kpsMTII, stxl, traT and cvaC) (De Brito et al, 2003).

E.coli strains were examined for detection of gene associated with outer membrane protein (genes encoding $\mathrm{P}$ fimbriae $p a p C$ ) and specific primers were utilized. The results demonstrated that virulence gene (papC) was carried by all examined E.coli strains isolated from broiler chickens with cellulitis. These results go ahead nearly with Gomis et al (2001) who found that papC gene expressed in $62.4 \%$ of E.coli isolates.

Some of the virulence factors such as aerobactin, fimbrial antigens and cytotoxins may enhance the ability of E.coli isolates to grow within the subcutaneous tissue of broilers (Ngeleka et al, 1996). Adherence of E.coli to the deeper and superficial tissue layers of the skin appears to be important in development of lesion and may be promoted by type 1 fimbriae (Gyles et al, 2004). Most APEC strains express type 1 fimbriae (F1 adhesin) characterized by their ability to bind D-mannose and thus bind to many types of eukaryotic cells. Binding is mediated via FimH subunit which is a minor component of the fimbriae (La Ragione and Woodward, 2002).

iss gene in an avian E.coli strain is a good indicator of bacterial capacity for causing disease, although its absence does not warrant lack of virulence of E.coli (PfaffMcDonough et al, 2000). Moreover, the iss gene occurs more frequently in APEC than strains from apparently healthy birds (McPeake et al, 2005; RodriguezSiek et al, 2005).

E.coli strains were examined by PCR for detection of the virulence gene (iss) and the result explained that $80 \%$ of the examined E.coli strains isolated from broiler chickens with cellulitis carried this gene. This concern correlated with Jeffrey et al (2002) who detected iss gene in $72 \%$ of E.coli isolates, while De Brito et al (2003) found iss gene in $83 \%$ and Barros et al (2013) identified iss gene by $87.9 \%$ in E.coli isolates from the cellulitis samples of broiler chickens. From 
human health hazard point of view this argument leads us to talk about the risks to public health where, the presence of iss gene in current assay may indicate a possible pathogenic potential of E.coli strains for human since the broiler chickens used in the assay were for human consumption.

E.coli uses iron for oxygen transport and storage, DNA synthesis, electron transport, and metabolism of peroxides (Neilands et al, 1985). Almost all iron in biological fluids is, however, complexed with host iron proteins. A host defense mechanism against bacterial infection is to further reduce the amount of iron available to the invading pathogen (Weinberg, 1978). Thus, bacteria need effective systems to meet their iron needs during infection. In E.coli, the siderophore aerobactin is the most effective of the several iron chelation systems employed by enteric bacteria for iron acquisition (Neilands et al, 1985). Isolates with the aerobactin system have a growth advantage in low-iron conditions (Montgomerie et al, 1984) and, in comparison to the other major specialized siderophore, enterobactin, aerobactin is more effective. In most isolates of E.coli, aerobactin is expressed by 5 operons, iucA-D and iutA. IutA is coding for the OMP receptor protein. Aerobactin determinants are found both on plasmids and on the bacterial chromosome (De Lorenzo et al, 1986).
The present result showed that E.coli isolates harbor aerobactin receptor gene (iutA) by $80 \%$ of the examined isolates from broiler chickens with cellulitis. This concern completely agreed with Gomis et al (2001) who found that iutA gene identified in E.coli isolates by $82.9 \%$, also Jeffrey et al (2002) and De Brito et al (2003) detected iutA gene by about $92 \%$ of E.coli isolates.

De Brito et al (2011) evaluated influence of the iss and iutA genes in the experimental pathogenicity of Escherichia coli and declared that the combination of these two genes results in worse lesions, which shows the characteristics of this multifactorial disease. They concluded that the iss and iutA genes serve as molecular markers for the virulence of cellulitisproducing E.coli isolates.

Resistance to normal serum has been associated with E.coli causing generalized infection in poultry and extra-intestinal infections in other species. This process is a complement-mediated event and is unrelated to the presence of specific antibodies. The majority of strains derived from birds with cellulitis and other lesions were resistant to killing by normal chicken serum and contained the traT gene, suggesting that serum resistance was also advantageous during the production of cellulitis (Harel et al, 1993 and Dozois et al, 1994).

E.coli isolates were examined for detection of outer membrane 
protein serum resistance gene ( $t r a T$ ) and it was found that the virulence gene (traT) was carried by all the examined E.coli strains isolated from broiler chickens with cellulitis. The obtained result agreed with that of Barbieri et al (2013) who found traT gene in $90 \%(129 / 144)$ of E.coli isolates from cellulitis lesions and with Ngeleka et al (1996) detected traT gene from E.coli isolated from cellulitis lesions by $72 \%$ (28/39). In the same context Gomis et al (2001) and De Brito et al (2003) detected traT gene in $60 \%$ of E.coli isolates from cellulitis lesions.

The virulence gene (kpsMTII) capsule polysaccharide export protein group 2 (K1-K5) was carried by $80 \%$ of the examined E.coli strains isolated from broiler chickens with cellulitis. This percentage was higher than that reported by Barbieri et al (2013) who detected kpsMTII gene in $37 \%$ (53/144) of E.coli isolates from cellulitis lesions and De Brito et al (2003) who detected kpsMTII gene in $31 \%(16 / 52)$ of E.coli isolates from cellulitis lesions. While the result do not match with Ngeleka et al (1996) and Jeffrey et al (2002) who found that the percentage of kpsMTII gene in E.coli strains isolated from broiler chickens with cellulitis was $8 \%$ and $6 \%$, respectively. Where, capsules have been associated with highly virulent avian E.coli strains (Gross, 1991). Capsules are also known to function in the prevention of phagocytosis by host's immune cells (Sussman, 1997). In the same context, the most common capsule types in avian E.coli are $\mathrm{K} 1$ and K80 (Gross, 1994). K1 capsules are poorly immunogenic and increase the serum resistance of E.coli strains (Dho-Moulin and Fairbrother, 1999), and strains that have these capsules are highly virulent (Ngeleka et al, 1996).

Concerning the temperature sensitive hemagglutinin gene (tsh), the result revealed that only $20 \%$ of the examined E.coli strains isolated from broiler chickens with cellulitis carried the virulence gene $(t s h)$. This concern goes parallel with $\boldsymbol{D e}$ Brito et al (2003) who detected tsh gene in $19 \%(10 / 52)$ of E.coli isolates from cellulitis lesions. While this result not matched with Barbieri et al (2013) who detected tsh gene in 66.6\% (96/144) of E.coli isolates from cellulitis lesions.

Shiga toxin 1 gene (stxl) was not detected in any examined E.coli strains isolated from broiler chickens with cellulitis. This result agreed to some extent with $\boldsymbol{D e}$ Brito et al (2003) who reported that stxl gene carried by only $6 \%$ (3/52) of E.coli strains isolated from cellulitis lesions from broiler chickens.

Although the role of colicin $\mathrm{V}$ in E.coli is controversial, production of this bacteriocin may indicate that an organism possesses a battery of properties associated with ColV plasmids, including serum resistance and an aerobactin iron uptake (Waters and Crosa, 1991). 
Previous reports indicate that the majority of E.coli isolates causing generalized infection in poultry produced colicin $\mathrm{V}$ and the siderophore aerobactin (Lafont et al, 1987). Ngeleka et al (1996) suggested that production of colicin $\mathrm{V}$ and production of aerobactin are also common characteristics of E.coli strains that cause cellulitis.

It was found that structural gene of colicin $\mathrm{V}(\mathrm{cvaC})$ was carried by $60 \%$ of the examined E.coli strains isolated from broiler chickens with cellulitis. This obtained result go ahead with Barbieri et al (2013) who reported that $c v a C$ gene carried by $60 \%(83 / 144)$ of E.coli strains isolated from cellulitis lesions from broiler chickens. While De Brito et al (2003) detected $c v a C$ gene in $48 \%(25 / 52)$ of E.coli strains isolated from cellulitis lesions from broiler chickens. On the other hand the obtained result was lower than that reported by Ngeleka et al (1996) who found that $c v a C$ gene carried by $92 \%$ (36/39) of E.coli strains isolated from cellulitis lesions from broiler chickens.

It could be concluded that, the results of this study indicated that cellulitis is caused by pathogenic E.coli isolates from different $\mathrm{O}$ serotyped groups and non-typed ones, which possess virulenceassociated genes varied in their distribution within these $\mathrm{O}$ serotypes. Examined strains of E.coli possess a characteristic set of virulence factors and that some of these virulent factors may be of public health concern. The occurrence of cellulitis and other diseases caused by E.coli and multiple lesions are not estimated, because other types of lesions may not be detected at the time of inspection, as the birds condemned for cellulitis are not examined. E.coli avian cellulitis may be associated with other virulence factors that have not been investigated.

\section{References}

Allan, B. J. (2012):"Escherichia coli cellulitis in broiler chickens: analysis of virulence factors." Western Meeting of Poultry Clinicians and Pathologists: 1-2.

Barbieri, N. L.; de Oliveira, A. L.; Tejkowski, T. M.; Pavanelo, D. B.; Rocha, D. A.; Matter, L. B.; Callegari-Jacques, S. M.; de Brito, B. G. and Horn, F. (2013):"Genotypes and pathogenicity of cellulitis isolates reveal traits that modulate APEC virulence." PLoS ONE. 8(8):e72322.

Barnes, H. J. and Gross, W. B. (1997):"Colibacillosis diseases of poultry." B. W. Calnek. Ames, Iowa, U.S.A., Iowa State University Press: 131-141.

Barros, L. S. S.; Silva, R. M.; Silva, I. M.; Baliza, M. D. and Virgilio,F.F. (2013):"Escherichia coli from cellulitis lesions in broilers." Food Measure. 7:40-45.

De Brito, B. G.; Gaziri, L. C. J. and Vidotto, M. C. (2003):"Virulence factors and 
clonal relationships among Escherichia coli strains isolated from broiler chickens with cellulitis." Infection and Immunity. 71(7):4175-4177.

De Brito, B. G.; Tejkowski, T. M.; Oliveira, G. A.; Soares, B. D.; Jaenisch, F. R. F.; Obara, V. Y.; Silva, S. M. H.; Torres, A. R.; Domingues, J.; Melo, R. O. and Brito, K. C. T. (2011):"Cellulitisassociated bacterial virulence and resistance of broiler strains." Latin American Poultry Congress: 1-3.

Delicato, E. R.; de Brito, B.G.; Gaziri, L. C. J. and Vidotto, M.C. (2003): "Virulence-associated genes in Escherichia coli isolates from poultry with colibacillosis." Veterinary Microbiology. 94:97103.

De Lorenzo, V.; Bindereif, A.; Paw, B. H. and Neilands, J. B. (1986): "Aerobactin biosynthesis and transport genes of plasmid ColV- K30 in Escherichia coli K12." J. Bacteriol. 165:570-578.

Derakhshanfar, A. and Ghanbarpour, R. (2002): "A study on avian cellulitis in broiler chickens." Vet. Arhiv. 72:277-284.

Dho-Moulin, M. and Fairbrother, J. M. (1999):"Avian pathogenic Escherichia coli (APEC)." Veterinary Research. 30:299-316.

Dipineto, L.; Santaniello, A.; Fontanella, M.; Lagos, K.; Fioretti, A. and Menna, L. F. (2006):"Presence of Shiga toxinproducing Escherichia coli O157:H7 in living layer hens."
Letters in Applied Microbiology. 43:293-295.

Dozois, C. M.; Chanteloup, N.; Dho-Moulin, M.; Bree, A.; Desautels, C. and Fairbrother, J. M. (1994):"Bacterial colonization and in vivo expression of F1 (type 1) fimbrial antigens in chickens experimentally infected with pathogenic Escherichia coli." Avian Diseases. 38:231-239.

Dziva, F. and Stevens, M. P. (2008):"Colibacillosis in poultry: unraveling the molecular basis of virulence of avian pathogenic Escherichia coli in their natural hosts." Avian Pathology. 37:355366.

Elfadil, A. A.; Vaillancourt, J. P.; Meek, A. H. and Gyles, C. L. (1996):

"A prospective study of cellulitis in broiler chicks in Southern Ontario." Avian Diseases. 40(3):677-689.

Ewers, C.; Li, G.; Wilking, H.; Kiebling, S.; Alt, K.; Antáo, E. M.; Laturnus, C.; Diehl, I.; Glodde, S.; Homeier, T.; Böhnke, U.; Steinrück, H.; Philipp, H. C.; Wieler, L. H. (2007):"Avian pathogenic, uropathogenic, and newborn meningitis-causing Escherichia coli: How closely related are they?" International Journal of Medical Microbiology. 297:163-176.

Gomis, S. M.; Goodhope, R.; Kumor, N.; Caddy, C.; Riddell, C.; Potter, A. A. and Allan, B. J. (1997):"Isolation of Escherichia coli from cellulitis and other lesions 
of the same bird in broilers at slaughter." Can Vet J. 38:159-162.

Gomis, S. M.; Riddell, C; Potter, A. A. and Allan, B. J. (2001):"Phenotypic and genotypic characterization of virulence factors of Escherichia coli isolated from broiler chickens with simultaneous occurrence of cellulitis and other colibacillosis lesions." The Canadian Journal of Veterinary Research. 65:1-6.

Gross, W. B. (1991):"Colibacillosis diseases of poultry." B. w. Calnek, H. J. Barnes, C. W. Beard, W. M. Reid and H. W. Yoder. Ames, Iowa, U.S.A., Iowa State University Press: 138-144.

Gross, W. B. (1994):"Diseases due to Escherichia coli in poultry." C. L. Gyles (ed.), Escherichia coli in domestic animals and human. $\mathrm{CAB}$ International, Wallingford, United Kingdom: 237-259.

Gyles, C. L.; Prescott, J. F. and Songer, J. G. (2004):"Pathogenesis of bacterial infections in animals." Third Ed. Blackwell, London.

Harel, J.; Fairbrother, J. M.; Forget, C.; Desautels, C. and Moore, J. (1993): "Virulence factors associated with F165-positive Escherichia coli strains isolated from piglets and calves." Vet. Microbiol. 38:139155.

Holland, J. L.; Louise, L.; Simor, A. E. and Louie, M. (2000):"PCR detection of Escherichia coli O157:H7 directly from stools: evaluation of commercial extraction methods for purifying fecal DNA."
Journal of Clinical Microbiology. 38 (11):4108 - 4113.

Hu, Q.; Tu, J.; Han, X.; Zhu, Y.; Ding, C. and Yu, S. (2011): "Development of multiplex PCR assay for rapid detection of Riemerella anatipestifer, Escherichia coli, and Salmonella enterica simultaneously from ducks." Journal of Microbiological Methods. 87:64-69.

Jeffrey, J. S.; Nolan, L. K.; Tonooka, K. H.; Wolfe, S.; Giddings, C. W.; Horne, S. M.; Foley, S. L.; Lynne, A. M.; Ebert, J. O.; Elijah, L. M.; Bjorklund, G.; Pfaff-McDonough, S. J.; Singer, R. S. and Doetkott, C. (2002):"Virulence factors of Escherichia coli from cellulitis or colisepticemia lesions in chickens." Avian Diseases. 46:48-52.

Johnson, T. J.; Siek, K. E.; Johnson, S. J. and Nolan, L. K. (2006):"DNA sequence of a ColV plasmid and prevalence of selected plasmid encoded virulence genes among avian Escherichia coli strains." Journal of Bacteriology. 188:745-758.

Kaipainen, T.; Pohjanvirta, T.; Shpigel, N. Y.; Shwimmer, A.; Pyörälä, S. and Pelkonen, S. (2002):"Virulence factors of E.coli isolated from bovine clinical mastitis." Vet Microbiol. 85(1):3746.

Lafont, J. P.; Dho, M.; D'Hauteville, H. M.; Bree, A. and Sansonnetti, P. J. (1987):"Presence and expression of aerobactin genes in virulent avian strains of 
Escherichia coli." Infection and Immunity. 55:193-197.

La Ragione, R. M. and Woodward, M. J. (2002): "Virulence factors of Escherichia coli serotypes associated with avian colisepticaemia." Research in Veterinary Science. 73:27-35.

Lee, G. Y.; Janga, H. I.; Hwangb, I. G. and Rheea, M. S. (2009):"Prevalence and classification of pathogenic Escherichia coli isolated from fresh beef, poultry, and pork in Korea." Int. J. Food Microbiol. 134(3):196200.

Lisa, K. N.; Barnes, J.; Jean-Pierre, V.; Tahseen, A. A. and Catherine, M. L. (2013): Colibacillosis in: Diseases of Poultry, 13th Edition. Swayne, David E. (Editor in chief) ISBN: 978-0-470-95899-5.

McPeake, S. J. W.; Smyth, J. A. and Ball, H. J. (2005):"Characterisation of avian pathogenic Escherichia coli (APEC) associated with colisepticaemia compared to faecal isolates from healthy birds." Veterinary Microbiology. 110:245253.

Mellata, M.; Ameiss, K.; Mo, H. and Curtiss, R. III. (2010): "Characterization of the contribution to virulence of three large plasmids of avian pathogenic Escherichia coli chi 7122 (O78:K80:H9)." Infection and Immunity. 78:1528-1541.

Mohamed, K. M.; Al-Demerdash, M. Z. and Eissa, A. I.
(1997):"Studies on swollen head syndrome in chicken." Ph.D. Thesis of poultry diseases submitted to Faculty of Veterinary Medicine, Suez Canal University.

Montgomerie, J. Z.; Bindereif, A.; Neilands, J. B.; Kalmanson, G. M. and Guze, L. B. (1984):"Association

hydroxamate siderophore (aerobactin) with Escherichia coli isolated from patients with bacteraemia." Infection and Immunity. 46:835-838.

Murray, P. R.; Baron, E. J. O.; Pfaller, M. A.; Jorgensen, J. H. and Yolken, R. H. (2003):"Manual of clinical microbiology." $8^{\text {th }}$ Ed., Vol.1, ASM press, Washington D. C.

Neilands, J. B.; Bindereif, A. and Montgomerie, $\quad$ J. $\quad Z$. (1985):"Genetic basis of iron assimilation in pathogenic Escherichia coli." Curr. Top Microbiol. Immunol. 118:179-195. Ngeleka, M.; Kwaga, M. J. K.; White, D. G.; Whittam, T. S.; Riddell, C.; Goodhope, R.; Potter, A. A. and Allan, B. (1996):"Escherichia coli cellulitis in broiler chickens: clonal relationships among strains and analysis of virulence-associated factors of isolates from diseased birds." Infection and Immunity. 64(8):3118-3126.

Norton, R. A. (1997):"Avian cellulitis." World's Poultry Science Journal. 53:337-349.

Norton, R. A.; Macklin, K. S. and MCMurtrey, B. L. (2000):"The 
association of various isolates of E.coli from U.S. with induced cellulitis and colibacillosis in young broiler chickens." Avian Pathology. 29:571-574.

Onderka, D. K.; Hanson, J. A.; McMillan, K. R. and Allan, B. (1997): "Escherichia coli associated cellulitis in broilers: correlation with systemic infection and microscopic visceral lesions and evaluation for skin trimming." Avian Diseases. 41:935-940.

Peighambari, S. M.; Vaillancourt, J. P.; Wilson, R. A. and Gyles, C. L. (1995):"Characteristics of Escherichia coli isolates from avian cellulitis." Avian

Diseases. 39:116-124.

Pfaff-McDonough, S. J.; Horne, S. M.; Giddings, C. W.; Ebert, J. O.; Doetkott, C.; Smith, M. H. and Nolan, $L$. $K$. (2000):"Complement resistancerelated traits among Escherichia coli isolates from apparently healthy birds and birds with colibacillosis." Avian Diseases. 44:23-33.

Randall, C. J.; Meakins, P. A.; Harris, M. P. and Watt, D. J. (1984):"A new skin disease in broilers?" Vet Rec: 114-246.

Rodriguez-Siek, K. E.; Giddings, C. W.; Doetkott, C.; Johnson, T. J. and Nolan, L. K. (2005):"Characterizing the APEC pathotype." Veterinary Research. 36: 241-256.

Sambrook, J.; Fritscgh, E. F. and Mentiates, T. (1989):"Molecular coloning." A laboratory manual. Vol!., Cold spring Harbor Laboratory press, New York.

Sussman, M. E. (1997): "Escherichia coli Mechanisms of Virulence." New York, NY, U.S.A., Cambridge University Press.

Waters, L.V. and Crosa, J. H. (1991):"Colicin V virulence plasmids." Microbiol. Rev. 55:437450.

Weinberg, E. D. (1978):"Iron and infection." Microbiol. Rev. 42:4566.

Wen-jie, J.; Zhi-ming, Z.;Yongzhi, Z.; Ai-jian, Q.; Hong-xia, S.;Yue-long, L.;Jiao, W. and Qian-qian W. (2008):"Distribution of Virulence-Associated Genes of Avian Pathogenic Escherichia coli Isolates in China." Agricultural Sciences in China. 7(12): 15111515.

Yaguchi, K.; Ogitani, T.; Osawa, R.; Kawano, M.; Kokumai, N.; Kaneshige, T.; Noro, T.; Masubuchi, K. and Shimizu, Y. (2007):"Virulence Factors of Avian Pathogenic Escherichia coli Strains Isolated from Chickens with Colisepticemia in Japan." Avian Diseases. 51(3):656-62. 


\section{التحديد الجزيئي لبعض جينات الضراوة للإيشيرشيا كولاي المسببة للإلتهاب الخلوي فى بداري التسمين بمحافظة الإسماعيلية لفيلية}

\section{محمد السيد عنانى ، *محمد كمال مرسى و *رنا محمد عبد القتاح}

قسم البكتريا والمناعة والفطريات. كلية الطب البيطرى. جامعة قناة السوبيس.

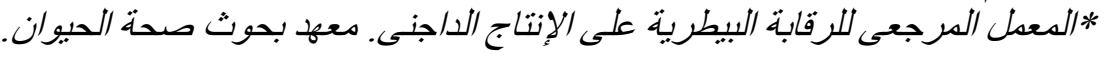

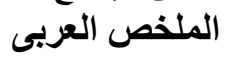

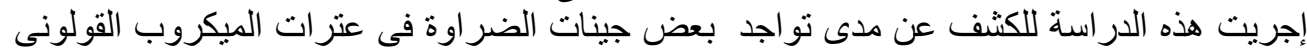

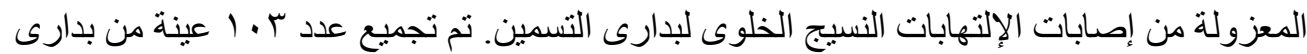

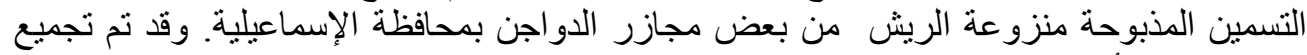

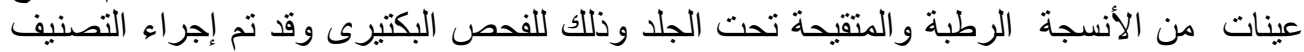

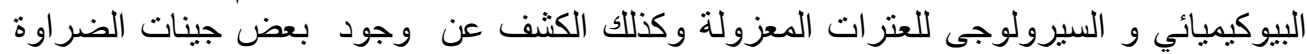

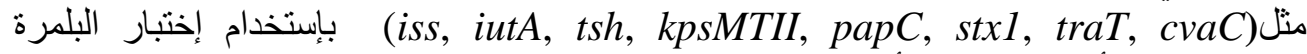

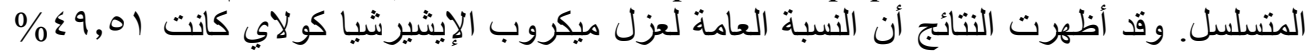

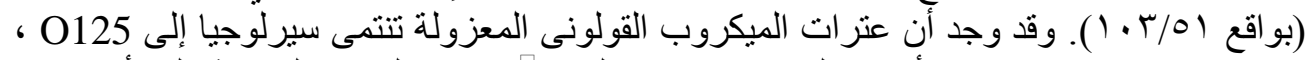

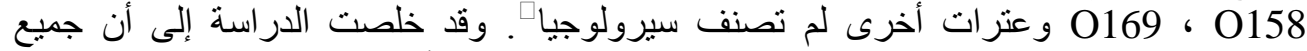

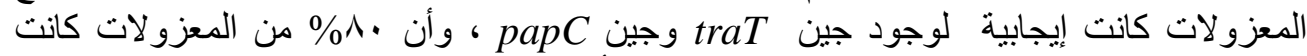

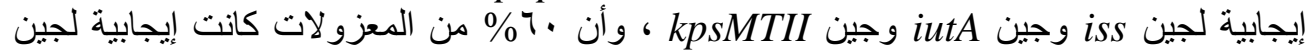

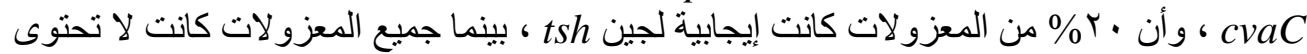
على جين stx1. 